\title{
Rural Entrepreneurship through Micro Finance, Bank Lending and Subsidy in Karnataka
}

\section{Ramakrishna $\mathrm{K}^{*}$}

Institute of Development Studies, University of Mysore, Manasagangothri, Mysore, Karnataka, India

\begin{abstract}
Women from the weaker sections of the society organized in to Self Help Groups (SHG) are running enterprises in various regions in both urban and rural India. These enterprises belong to sectors like agriculture, manufacturing and services. The initial capital required for the micro venture may come through micro credit which in many cases is supplemented by bigger loans through linkage of the SHG with some nationalized bank in the area, and in some cases may also receive bank end subsidy support. These micro ventures have been initiated with the objective of providing a means of livelihood to the members and some have been successful as they have provided a decent income to the members while some others have not. The reason may be many and the study tries to identify some of the enabling performance factors. The research looks at the performance of 125 micro enterprises that have been facilitated by a government run programme in Karnataka. Majority of these enterprises had received training and subsidy support from the government, under various subsidy and employment promotion programmes. The study is cross sectional and compares group run enterprises engaged in different entrepreneurial activity. A number of factors may have resulted in better performance, which is measured primarily in terms of turnover growth and growth in per capita income from the enterprise for those engaged in the group run entrepreneurial activity. The study suggests that choice of the activity, forward or market linkages, hand holding support for an extended period of time maybe more vital than subsidy for successful micro entrepreneurship promotion and only then there would be sustainable income generation from the entrepreneurial activity, which would ensure inclusive growth.
\end{abstract}

Keywords: Rural enterprises; Performance; Sustainable income; Subsidy

\section{Introduction}

'Inclusive growth', a concept that has grown in popularity in India and elsewhere in recent years according to the Commission on Growth and Development of the World Bank [1], encompasses equity, equality of opportunity, protection in market and employment transitions, and is an essential ingredient of any successful growth strategy. The Indian economy, which has been registering a steady growth in recent years, continues to battle poverty. It has been observed that some level of growth is a necessary condition for sustained poverty reduction, but Ali and Son [2] and others agree that growth by itself is not a sufficient condition for eradicating poverty. Growth alone, as Nayak et al. [3] mentions, may marginalize the poor sections and increase inequality, which may slowdown the growth process. One important reason for inadequate inclusion in India is that poverty reduction in the last decade has not kept pace with rising growth, and the poverty rate has declined only by less than 1 percent per annum over the past decade, markedly below trends in neighboring countries such as Nepal and Bangladesh.

The approach paper to the $11^{\text {th }}$ Five year plan points out that growth oriented policies should be combined with policies ensuring broad based per capita income growth, benefiting all sections of the population, particularly those who were deprived like the poor and the marginalized. Equitable and inclusive growth requires employment generation, which would ensure sustainable livelihoods to the poor and the marginalized in the urban and rural areas of the country. Self-employment can be generated through the development of micro enterprises and according to Otero and Rhyne "for increasing numbers of poor people around the world, micro enterprises are a source of income and employment where no other alternatives are available". These enterprises which require only a small amount of initial investment enable income generation through self-employment and ensure livelihood security for the poor. Rural micro entrepreneurship can lead to generation of higher non-farm employment and incomes leading to inclusive and sustainable development. A number of micro enterprises have been promoted through micro-credit which is a main component of microfinance, a tool for providing finance to the poor, and in the words of Koveos and Randhawa [4].

"The heart of the idea of microfinance is the belief that poverty can be reduced and eventually eliminated through provision of credit to those too poor to access the formal financial system".

\section{Review of Literature}

The objective of microfinance, considered as a grassroots instrument to alleviate poverty by many researchers, Anderson et al., Evans et al. $[5,6]$ is primarily to be achieved through micro enterprises that would ensure livelihoods. Anderson and Locker, McKernan, Hermes et al $[5,7,8]$, in separate studies conducted in some of the developing regions had reported that various social programs providing micro-loans without collateral have helped the poor to earn their livelihood thereby leading to social and economic development in these areas.

Micro enterprises require small loans, or 'Microcredit' which is the term used for extending of small loans to very poor people, especially women, for generating income through self-employment activities. Kulshreshtha identified that lack of capitals as a major constraint to the development of women owned enterprises in rural areas, which was

*Corresponding author: Ramakrishna K, Institute of Development Studies, University of Mysore, Manasagangothri, Mysore, Karnataka State, India, Tel: 821 2419794; E-mail: ramakrishnak643@gmail.com

Receved February 08, 2014; Accepted July 07, 2014; Published July 17, 2014

Citation: Ramakrishna K (2014) Rural Entrepreneurship through Micro Finance, Bank Lending and Subsidy in Karnataka. J Entrepren Organiz Manag 3: 113. doi: 10.4172/2169-026X.1000113

Copyright: ( 2014 Ramakrishna K, et al. This is an open-access article distributed under the terms of the Creative Commons Attribution License, which permits unrestricted use, distribution, and reproduction in any medium, provided the original author and source are credited. 
mainly due to lack of identity and assets as collateral security. Dowla has mentioned that it was the Grameen Bank of Bangladesh that pioneered lending without any collateral to the poor, especially to groups of poor women, who were illiterate and landless. The advent of microfinance and micro-credit and the self-help grouping as Shylendra [9] mentions brought about a change in to this, bringing about greater inclusion of the poor especially the women, into the formal banking sector.

The objective of microcredit according to Anderson et al. [5] is to break the vicious circle of poverty consisting of low capital, productivity, income and savings and is intended to enable the borrowers, primarily the poor women, to buy the goods that are needed to start or improve a small business. Lepenies [10], wrote that the poor commonly face obstacles in the form of unfavorable market environments, inadequate financial infrastructure, location, market and infrastructure constraints, with poor transport infrastructure being one of the important impediment to rural microenterprise development.

The Asian Development Bank (ADB) has grouped micro enterprises into high return entrepreneurial and low return survival activities with the former being larger, more highly capitalized, employing more number of labours and using better technologies. They also tend to operate continuously, reinvest surpluses, and are usually primary household income sources mostly operated by men across regions, insulated from seasonal fluctuations and exhibiting lesser closure rates in comparison. Survival activities on the other hand are usually secondary sources of income and are mostly operated by women. They are characterized by low barriers to entry, undifferentiated products, saturated markets and inefficiencies which limit their competitiveness. They often rely on inputs which their owners gather themselves from locally available sources which may be seasonal and the production processes are also prone to climatic fluctuations leading to very few of these enterprises earn income which is very close to the poverty line.

Mead and Leidholm [11] defined micro enterprises as those requiring very small amount in terms of start-up capital, with initial capital requirements ranging from 49 dollars in Sierra Leone to 2,04 dollars in Jamaica. Dhar who researched on IRDP, identified microenterprises as those whose loan requirement was ranging from Rs.6,000 and Rs.10,000. Many of them may be involved in activities ranging from part-time income-generating activities run by individuals, to larger family-operated enterprises and also smaller enterprises employing hired labour. They may encompass all types of urban and non-farm rural activities, extending from manufacturing to commerce and even include enterprises engaged in transport business. Variations in business type, based on agricultural seasons were common in the rural areas. The researchers also recorded that in the case of womenowned and operated microenterprises, the cash associated with one microenterprise were frequently mingled with that of other household activities, including other enterprises.

As sustainable micro enterprises can ensure and provide livelihoods for the poor, it can play a role in alleviating poverty, but the degree of permanence, productivity and profitability varies considerably among these micro enterprises. The study aims to look into the performance of women run micro enterprises in rural areas, particulars by group of women who had grouped themselves in to self-help groups.

\section{Research Methodology}

One twenty six group run microenterprises from fifteen panchayats in the district of Mysore in Karnataka were selected for the study. All enterprises selected were house which were in operation at least for a minimum period of eighteen months, and had established after 2002, with about 75 per cent of those selected being established after 2009 These were owned and operated by women belonging to self-help groups promoted with the handholding support of government run poverty eradication programme in the state.

Data was collected by the interviewing the women who were running the enterprises using a structured questionnaire. The performance of enterprises is measured based on the average monthly turnover and the average monthly income generated per member. The research particularly looked at the impact of subsidy in terms of activity as well as income generation per member as the parameter was considered to be an important performance measure of the enterprise. This was since many of these group run enterprises, were run by two to twenty members, which therefore resulted in wide variations in average income that each received in spite of similar growth in turnover or other aspects.

\section{Data Description}

In all, there were 16 tailoring units; 10 units each of rice \& spice powders and catering units; 7 provisions stores; 5 each of restaurants and bakeries; 4 pickle units and 4 papad units; there were also 3 DTP centers, 2 units making artificial jewellery, 7 units each of bamboo based handicrafts and paper plates, soap and detergents and 6 paper bag units. There were 2 oil processing units 3 units each of fish processing; candle making units and rice mills; 4 goat rearing units and 5 dairy units. The rest of the units were all single units representing activities like candle and umbrella making, honey making, direct marketing and others.

The enterprises were categorized in to five groups on the basis of the capital invested. In category A the enterprise had made a maximum initial investment of Rs.49, 999, while in B it was 99,999. The category C had 1, 49, 999, D had 1, 99,999 as the maximum limit, while enterprises in category $\mathrm{E}$ had an initial investment of Rs.2, 00,000 and above. Out of all units there were 29 in category A, 17 Category B, 36 in category C, 4 units in category D, and 39 in category E.

\section{Results and Discussions}

\section{Status and activity areas of rural enterprises}

The activities areas of the enterprises studied and the status of the enterprise in 2012 is represented in Table1 from which it can be observed that 33 surveyed were already closed out of the 126 units (26.19\%) or had become totally inactive.

It can be observed that 20 percent of the enterprises engaged in service activities had closed, while it was 28,13 in the case of food processing and 32 per cent in the case of manufacturing enterprises. The highest percentage of closed enterprises were found I those engaged in handicraft activities, while in the case of livestock enterprises, it was the least.

In the case of enterprises engaged in service activities, 40 percent

\begin{tabular}{|c|c|c|c|c|c|}
\hline S. No. & Activity & Working & Closed & \% Closed & Total \\
\hline 1 & Service & 36 & 9 & 20.00 & 45 \\
\hline 2 & Food Processing & 23 & 9 & 28.13 & 32 \\
\hline 3 & Manufacturing & 17 & 8 & 32.00 & 25 \\
\hline 4 & Hand crafts & 8 & 6 & 42.86 & 14 \\
\hline 5 & Livestock & 9 & 1 & 10.00 & 10 \\
\hline & Total & $\mathbf{9 3}$ & $\mathbf{3 3}$ & $\mathbf{2 6 . 1 9}$ & $\mathbf{1 2 6}$ \\
\hline
\end{tabular}

Table 1: Activity areas of Rural Enterprises Source: Field data. 


\begin{tabular}{|c|c|c|c|c|c|}
\hline S. No. & Activity & Working & Closed & \% Closed & Total \\
\hline 1 & Catering & 6 & 4 & 40.00 & 10 \\
\hline 2 & Restaurant & 4 & 1 & 20.00 & 5 \\
\hline 3 & Canteen & 1 & 0 & 0 & 1 \\
\hline 4 & Data Entry & 2 & 1 & 33.33 & 3 \\
\hline 5 & Provision Store & 6 & 1 & 14.29 & 7 \\
\hline 6 & Tailoring \& Ready made & 14 & 1 & 6.67 & 15 \\
\hline 7 & Direct marketing & 2 & 1 & 33.33 & 3 \\
\hline 8 & Traditional Art Troupe & 1 & 0 & 0 & 1 \\
\hline & Total & $\mathbf{3 6}$ & $\mathbf{9}$ & $\mathbf{2 0 . 0 0}$ & $\mathbf{4 5}$ \\
\hline
\end{tabular}

Table 2: Enterprises engaged in Service Activities.

\begin{tabular}{|c|c|c|c|c|c|}
\hline S.No. & Activity & Working & Closed & $\%$ Closed & Total \\
\hline 2 & Umbrella \& Bags & 1 & 1 & 50.00 & 2 \\
\hline 3 & Paper plate (Machine made) & 4 & 2 & 33.33 & 6 \\
\hline 4 & Soap/Detergent & 2 & 5 & 71.43 & 7 \\
\hline 5 & Candle making & 3 & 0 & 0 & 3 \\
\hline 6 & Knife Grinding & 1 & 0 & 0 & 1 \\
\hline 7 & Compost/ Coir making & 2 & 0 & 0 & 2 \\
\hline & Total & $\mathbf{1 7}$ & $\mathbf{8}$ & $\mathbf{3 2 . 0 0}$ & $\mathbf{2 5}$ \\
\hline
\end{tabular}

Table 3: Enterprises engaged in Manufacturing Activities.

of catering enterprises and 33.33 per cent of the direct marketing units had closed down as can be observed in Table 2 .

In the case of enterprises engaged in manufacturing activities, as shown in Table 3, 71.43 per cent of the soap and detergent making micro enterprises had closed down while 33.33 per cent of the paper plate making units had closed down.

\section{Status of enterprises and monthly income in 2010 for selected activities}

Average Monthly Income one person received form the enterprise in 2010 at Inception were studied and is depicted for certain selected activities in the tables below;

Per capita Monthly Income from Catering Enterprises Table 4 exhibits the average monthly income at the first and the last year of operation for 'Inactive' or 'closed' catering enterprises. It can be observed that the average monthly income obtained from the enterprises was very low (not above Rs.500 except for one enterprise). The reasons for closure were lack of demand, inability to withstanding competition, financial mismanagement etc. All catering enterprises were operated from home and members in some cases were not proactive in getting orders, which seemed to be main reason for low levels of average per capital income, resulting in lack of motivation to continue with the enterprise.

In the case of active Enterprises, the members had received higher levels of monthly income from the enterprise right from the beginning as can be observed in Table 5 .

Table 5 exhibits the average monthly income at the first and the last year of operation for active' catering enterprises, that is definitely higher than those that became inactive. It was also observed that the number of members decreased to 4 in two enterprises that began with 5 members and to 3 in one. In both the 10 member enterprises the number of members had not decreased. The reason behind the enterprise with two members showing a remarkably higher monthly income was that they were running the hostel of an establishment in the urban area nearby. Hence the enterprise could not be strictly counted as a catering enterprise which had to 'canvass' clients and operate under 'uncertain' demand conditions like others in the group.
Per capita Monthly income from Tailoring Enterprises Table 6 exhibits the average monthly income at the first and the last year of operation for closed tailoring enterprises. It was observed that only two tailoring enterprises had become 'inactive' out of which one not a typical tailoring unit as it was a 'hand embroidery unit'. The remaining 14 out of the total 15 units were active.

It was also observed that in 57.2 per cent of the active enterprises in Table 6 the number of members had reduced over the years while in 42.8 per cent of the enterprises, all the members who were at the inception of the enterprises continued to be active.

\section{Performance of enterprises in terms of turnover growth and income per member}

The performance of enterprises was looked at in terms of growth in turnover of the enterprise (value of total monthly sales) and average monthly income that every woman earned from the group enterprise. It can be observed from Table 4 that the increase in income did not keep pace with the turn over growth in firms engaged in similar activities. This might be caused due to various reasons; the increase in turnover did not reflect increase in average income as there were large number of members present in the group enterprise, and hence there was no proportional growth in average monthly income received by each, inspite of growth in enterprise turnover; There may also be increase in

\begin{tabular}{|c|c|c|c|}
\hline $\begin{array}{c}\text { No. of members } \\
\text { at Inception }\end{array}$ & $\begin{array}{c}\text { Av. Monthly income } \\
\text { at Inception }\end{array}$ & $\begin{array}{c}\text { Av. Monthly } \\
\text { income in last year }\end{array}$ & $\begin{array}{c}\text { No. of active } \\
\text { years }\end{array}$ \\
\hline 5 & 500 & 800 & 3 \\
\hline 10 & 250 & 250 & 6 \\
\hline 5 & 500 & 300 & 2 \\
\hline 5 & 200 & 200 & 1 \\
\hline
\end{tabular}

Table 4: Average Per capita Monthly Income for Inactive Catering Enterprises.

\begin{tabular}{|c|c|c|c|}
\hline $\begin{array}{c}\text { No. of members } \\
\text { at Inception }\end{array}$ & $\begin{array}{c}\text { Av. Monthly income } \\
\text { at Inception }\end{array}$ & $\begin{array}{c}\text { Av. Monthly income } \\
\text { in last year }\end{array}$ & $\begin{array}{c}\text { No. of active } \\
\text { years }\end{array}$ \\
\hline 2 & 6000 & 7000 & 3 \\
\hline 5 & 500 & 2500 & 3 \\
\hline 5 & 500 & 1500 & 4 \\
\hline 5 & 1000 & 3875 & 7 \\
\hline 10 & 500 & 1250 & 5 \\
\hline 10 & 750 & 2000 & 3 \\
\hline
\end{tabular}

Table 5: Average Per capita Monthly Income for Active Catering Enterprises.

\begin{tabular}{|c|c|c|c|}
\hline $\begin{array}{c}\text { No. of members } \\
\text { at Inception }\end{array}$ & $\begin{array}{c}\text { Av. Monthly income } \\
\text { at Inception }\end{array}$ & $\begin{array}{c}\text { Av. Monthly income } \\
\text { in last year }\end{array}$ & $\begin{array}{c}\text { No. of active } \\
\text { years }\end{array}$ \\
\hline 6 & 500 & 1500 & 4 \\
\hline 5 & 800 & 2000 & 6 \\
\hline 5 & 500 & 3000 & 3 \\
\hline 5 & 500 & 2800 & 4 \\
\hline 11 & 400 & 500 & 2 \\
\hline 11 & 200 & 500 & 3 \\
\hline 5 & 500 & 1000 & 2 \\
\hline 5 & 500 & 2750 & 3 \\
\hline 5 & 200 & 1300 & 3 \\
\hline 10 & 1000 & 2917 & 4 \\
\hline 13 & 250 & 2000 & 4 \\
\hline 5 & 500 & 1200 & 3 \\
\hline 18 & 100 & 1000 & 5 \\
\hline 5 & 500 & 3100 & 4 \\
\hline
\end{tabular}

Table 6: Average Per capita Monthly Income for Active TailoringEnterprises. 
raw material prices which may have reduced margins and profits left for sharing among the members.

There may also be paid employees which reduces the average income received by each member.

It was observed that level of subsidy and capital invested alone may not ensure better performance in terms of member income and turnover $r$ growth, as can be observed from Table 7 Same is the case for rice and spice powder enterprises where those with double the capital and subsidy (Table 8 ) were not exhibiting similar growth in terms of turnover and per capita income

In case of handicraft enterprises, it was observed that per capita income growth was lower than turnover growth in all cases, and negative in many as can be observed from Table 9 The performance differed widely for enterprises with similar initial capital and subsidy with the enterprise that received highest subsidy showing negative turn over and per capita income growth, showing some decline.

In the case of tailoring enterprises (Table 10) it is also observed that in six of the enterprises, per capita income growth was higher than turnover growth. This may be primarily because it is a service enterprise, as most of these stitch according to order.

In Table 11 the Initial capital and subsidy of dairy enterprises is exhibited. All enterprises had invested same amount of initial capital and had received equal subsidy.

The turnover growth and per capita income growth was similar in this case and may be because of the fact that when the enterprises was able to sell more milk, and as is turnover rose, the member income also rose primarily because they were able to compensate higher price rise in feed cost by increasing the milk prices.

\begin{tabular}{|c|c|c|c|}
\hline Initial Capital & Subsidy & Turnover Growth & Per capita income growth \\
\hline 60,000 & 0 & $13 \%$ & $17 \%$ \\
\hline 100,000 & 50,000 & $125 \%$ & $67 \%$ \\
\hline 105,000 & 50,000 & $220 \%$ & $400 \%$ \\
\hline 200,000 & 100,000 & $233 \%$ & $167 \%$ \\
\hline 100,000 & 50,000 & $150 \%$ & $25 \%$ \\
\hline 70,000 & 35,000 & $300 \%$ & $29 \%$ \\
\hline
\end{tabular}

Table 7: Initial Capital and Subsidy of Catering Enterprises.

\begin{tabular}{|c|c|c|c|}
\hline Initial Capital & Subsidy & Turnover Growth & Per capita income growth \\
\hline 40,000 & 20,000 & $0 \%$ & $17 \%$ \\
\hline 30,000 & 10,000 & $100 \%$ & $525 \%$ \\
\hline 5,000 & 0 & $100 \%$ & $33 \%$ \\
\hline 100,000 & 50,000 & $140 \%$ & $200 \%$ \\
\hline 86,000 & 43,000 & $-30 \%$ & $25 \%$ \\
\hline 105,000 & 50,000 & $73 \%$ & $75 \%$ \\
\hline 200,000 & 100,000 & $60 \%$ & $340 \%$ \\
\hline 80,000 & 40,000 & $100 \%$ & $260 \%$ \\
\hline
\end{tabular}

Table 8: Initial Capital and Subsidy of Rice \& Spice Powder Enterprises.

\begin{tabular}{|c|c|c|c|}
\hline Initial Capital & Subsidy & Turnover Growth & Per capita income growth \\
\hline 100,000 & 50,000 & $157 \%$ & $-20 \%$ \\
\hline 100,000 & 50,000 & $122 \%$ & $0 \%$ \\
\hline 100,000 & 50,000 & $133 \%$ & $200 \%$ \\
\hline 200,000 & 80,000 & $150 \%$ & $100 \%$ \\
\hline 200,000 & 100,000 & $-13 \%$ & $-85 \%$ \\
\hline
\end{tabular}

Table 9: Initial Capital and Subsidy of Handicraft Enterprises.

\begin{tabular}{|c|c|c|c|}
\hline Initial Capital & Subsidy & Turnover Growth & Per capita income growth \\
\hline 100,000 & 0 & $100 \%$ & $88 \%$ \\
\hline 100,000 & 50,000 & $64 \%$ & $33 \%$ \\
\hline 100,000 & 10,000 & $33 \%$ & $500 \%$ \\
\hline 25,000 & 10,000 & $200 \%$ & $40 \%$ \\
\hline 200,000 & 100,000 & $25 \%$ & $25 \%$ \\
\hline 440,000 & 110,000 & $33 \%$ & $150 \%$ \\
\hline 100,000 & 50,000 & $150 \%$ & $100 \%$ \\
\hline 60,000 & 30,000 & $213 \%$ & $450 \%$ \\
\hline 100,000 & 50,000 & $150 \%$ & $160 \%$ \\
\hline 100,000 & 50,000 & $200 \%$ & $46 \%$ \\
\hline 60,000 & 25,000 & $150 \%$ & $100 \%$ \\
\hline 100,000 & 50,000 & $50 \%$ & $140 \%$ \\
\hline 58,000 & 0 & $250 \%$ & $300 \%$ \\
\hline 60,000 & 10,000 & $300 \%$ & $107 \%$ \\
\hline
\end{tabular}

Table 10: Initial Capital and Subsidy of Tailoring Enterprises.

\begin{tabular}{|c|c|c|c|}
\hline Initial Capital & Subsidy & Turnover Growth & Per capita income growth \\
\hline 250,000 & 37,500 & $129 \%$ & $125 \%$ \\
\hline 250,000 & 37,500 & $86 \%$ & $96 \%$ \\
\hline 250,000 & 37,500 & $131 \%$ & $125 \%$ \\
\hline 250,000 & 37,500 & $125 \%$ & $50 \%$ \\
\hline 250,000 & 37,500 & $69 \%$ & $60 \%$ \\
\hline
\end{tabular}

Table 11: Initial Capital and Subsidy of Dairy Enterprises.

\section{Policy Implication and Conclusion}

As was seen in the case of the In the case of catering, despite subsidy support, many could not survive as they could not compete effectively in the market. Those who have survived have done so because they were proactive and the member were determined to make their enterprise survive in spite of many obstacles that had come in their way over the years. Tailoring enterprises were better in comparison to many as there was a certain amount of 'local demand' that was captured by most of the enterprises selected in the sample.

Rural entrepreneurship would help to generate sustainable livelihoods and inclusive growth if the enterprise activity is suitable for the micro as well as the macro environment. Market demand for the product is critical to the success and long term growth. Enterprise activity should either meet in unmet need of the local or a marketable population. Marketing tie ups and forward linkages may help the firm more than the subsidy, and therefore support strategies other than subsidy may have to be devised for the long term sustainability of such micro enterprises.

\section{References}

1. Commission on Growth and Development (2008) Growth Report: Strategies for Sustained Growth and Inclusive Development, World Bank, Washington DC.

2. Ali I, Son HH (2007) Measuring Inclusive Growth, Asian Development Review, 24: 11-31.

3. Nayak PK, Chattopadhyay SK, Kumar AV, Dhanya V (2010) Inclusive Growth and its Regional Dimension, Reserve Bank of India Occasional Papers, 31.

4. Koveos P, Randhawa D (2004) Financial services for the poor: assessing microfinance institutions, Journal of Managerial Finance, 30: 70-95.

5. Anderson CL, Locker L (2002) Microcredit, social capital and common pool resources, World Development, 30: 95-105

6. Evans TG, Adams AM, Mohammed R, Norris AH (1999) Demystifying nonparticipation in micro credit: a population-based analysis, World Development, 27: $419-430$. 
Citation: Ramakrishna K (2014) Rural Entrepreneurship through Micro Finance, Bank Lending and Subsidy in Karnataka. J Entrepren Organiz Manag 3: 113. doi: 10.4172/2169-026X.1000113

Page 5 of 5

7. McKernan SM (2002) The impact of micro-credit programs on self-employment profits: do non-credit program aspects matter? Review of Economics and Statistics, 84: 93-115.

8. Hermes N, Lensink R, Mehrteab HT (2005) Peer monitoring, social ties and moral hazard in group lending programs: evidence from Eritrea, World Development, 33: 149-69.
9. Shylendra HS (2008) Role of Self Help Groups, Yojana 25-28.

10. Lepenies PH (2004) Exit, Voice and Vouchers: Using Vouchers to Train Micro entrepreneurs- Observations from the Paraguayan Voucher Scheme, World Development 32: 713-724.

11. Mead DC, Leidholm C (1998) The Dynamics of Micro and Small Enterprises in Developing Countries, World Development, 26: 61-74. 